Original Research Article

\title{
To study the effect of various combinations of haart in CD4+ cell count in HIV patient at RIMS, Ranchi Art Centre
}

\author{
Sumit Kumar Mahato*, Uma Shanker Prasad Keshri, Akhilesh Kumar, \\ Pholgu Protim, Vineet Kumar
}

Department of Pharmacology and Therapeutics, Ranchi University, Jharkhand, India

Received: 22 January 2017

Accepted: 27 February 2017

\section{*Correspondence to:}

Dr. Sumit Kumar Mahato, Email: sumitpharmacology2015se18@g mail.com

Copyright: (C) the author(s), publisher and licensee Medip Academy. This is an openaccess article distributed under the terms of the Creative Commons Attribution NonCommercial License, which permits unrestricted noncommercial use, distribution, and reproduction in any medium, provided the original work is properly cited.

\begin{abstract}
Background: India has the third largest HIV epidemic in the world. In 2013, HIV prevalence in India was an estimated 0.3\%, an estimated 130,000 people died from AIDS-related illnesses. Overall, India's HIV epidemic is slowing down, with a $19 \%$ decline in new HIV infections (130,000 in 2013), and a 38\% decline in AIDS-related deaths between 2005 and 2013. Antiretroviral therapy (ART) for the treatment of HIV infection has improved steadily since the advent of potent combination therapy in 1996. ART has dramatically reduced HIVassociated morbidity and mortality. The aim of this study is to see the change in CD4+ count in patient taking various combination of HAART (Highly active anti-retroviral treatment).

Methods: A total of 215 patients were included in this study that came to the rims art centre for regular follow up and there cd4+ count at 6 monthly interval upto 18 months was taken and analysed.

Results: The patients were evaluated for their change in CD4+ cell count. Mean of CD4+ count at 6 monthly interval was taken in this study which showed that haart combination causes significant improvement in cd4+ count in each group (1) stavudine, lamivudine, nevirapine (2)stavudine, lamivudine, efavirenz (3) zidovudine, lamivudine, nevirapine (4) zidovudine, lamivudine, efavirenz, (5) tenofovir, lamivudine, efavirenz.

Conclusions: SLN combination was found most effective in increasing the CD4+ Cell count in comparision to the other combination. Other drugs combinations in decreasing order are as follows- SLE, ZLE, TLE, ZLN.
\end{abstract}

Keywords: CD4+ cell count, Highly active anti-retroviral treatment, Lamivudine, Nevirapine, Stavudine

\section{INTRODUCTION}

India has the third largest HIV epidemic in the world. In 2013, HIV prevalence in India was an estimated $0.3 \%$. This figure is small compared to most other middleincome countries but because of India's huge population (1.2 billion) this equates to 2.1 million people living with HIV. In the same year, an estimated 130,000 people died from AIDS-related illnesses. ${ }^{1}$ Overall, India's HIV epidemic is slowing down, with a $19 \%$ decline in new HIV infections (130,000 in 2013), and a 38\% decline in AIDS-related deaths between 2005 and 2013. Despite, this $51 \%$ of deaths in Asia are in India. ${ }^{1}$ HIV prevalence in India varies geographically. The five states with the highest HIV prevalence (Nagaland, Mizoram, Manipur, Andhra Pradesh and Karnataka) are in the south or east of the country. Some states in the north and northeast of the country, report rising HIV prevalence. ${ }^{2}$

Antiretroviral therapy (ART) for the treatment of HIV infection has improved steadily since the advent of potent combination therapy in 1996. ART has dramatically reduced HIV-associated morbidity and mortality and has transformed HIV infection into a manageable chronic condition. ${ }^{3}$ The primary goals of antiretroviral therapy are maximal and durable reduction in plasma viral levels, restoration of immunological functions aimed at prolongation of life and improvement in quality of life. The reduction in viral load also leads to reduction in risk 
of sexual transmission. Although most HAART( highly active antiretroviral therapy)-treated patients may eventually achieve an optimal CD4+ $\mathrm{T}$ cell count outcome, an important but poorly defined subset fail to achieve this result or do so only after many years of HAART. Those patients whose CD4+ T cell counts remain low during therapy have an increased risk of a number of complications, including those due to AIDS, as well as those not traditionally thought to be HIV related (e.g., cancer, cardiovascular disease, and liver disease). ${ }^{4}$ The definition of HAART followed the Department of Health and Human Services/Kaiser Panel guideline. ${ }^{5}$ HAART was defined as 1) use of two or more nucleoside (or nucleotide) reverse transcriptase inhibitors (NRTIs) in combination with at least one protease inhibitor or one non-NRTI; 2) use of one NRTI in combination with at least one protease inhibitor and at least one non-NRTI; 3) a regimen containing ritonavir and saquinavir in combination with one NRTI and no non-NRTIs; or 4) an abacavir-containing regimen of three or more NRTIs in the absence of both protease inhibitors and non-NRTIs. The guidelines on ART are issued and periodically updated by different expert groups like Department of Health and Human Services (DHHS), USA, British HIV Association (BHIVA) 2006, Association of Physicians of India 2006 and National AIDS Control Organisation in India. ${ }^{6-9}$ The recommendations on starting treatment are based on WHO clinical staging, CD4 cell counts, and viral load, if possible. $^{10,11}$ The ART guidelines by Association of Physicians of India recommended a determination of plasma viral load at six months to determine the efficacy of ARV regimen. ${ }^{12}$ With this idea in mind, this study was done to see the effect of various combination of HAART in patient with HIV coming to the Rajendra Institute of Medical Science, Ranchi ART centre.

The aim of this study is to see the change in CD4+ count in patient taking various combination of HAART (Highly active anti-retroviral treatment).

\section{METHODS}

This study was conducted in patient, who attended the ART centre at Rajendra Institute of Medical Sciences,
Ranchi for their follow up and were of either sex. A total of 215 patients were included in this study. Different combinations of HAART used in this study are (1) stavudine, lamivudine, nevirapine (2) stavudine, lamivudine, efavirenz (3) zidovudine, lamivudine, nevirapine (4) zidovudine, lamivudine, efavirenz, (5) tenofovir, lamivudine, efavirenz and no. patient enrolled in each regimen were $26,18,110,17,44$ respectively for each group. All patients of either sex who were strictly taking HAART combination and those who came for regular follow up for at least 2 years were included in this study and those who were lost in the follow up, either dead or not taking HAART on a regular basis and those patient taking medication for other disease like tuberculosis etc. were excluded from the study. CD4+ cell count was done at every 6 month, according to ART guideline by association of Physician of India. ${ }^{12}$

\section{RESULTS}

The patients were evaluated for their change in CD4+ cell count at every 6 month interval. Mean of CD4+ count at regular interval was taken in this study.

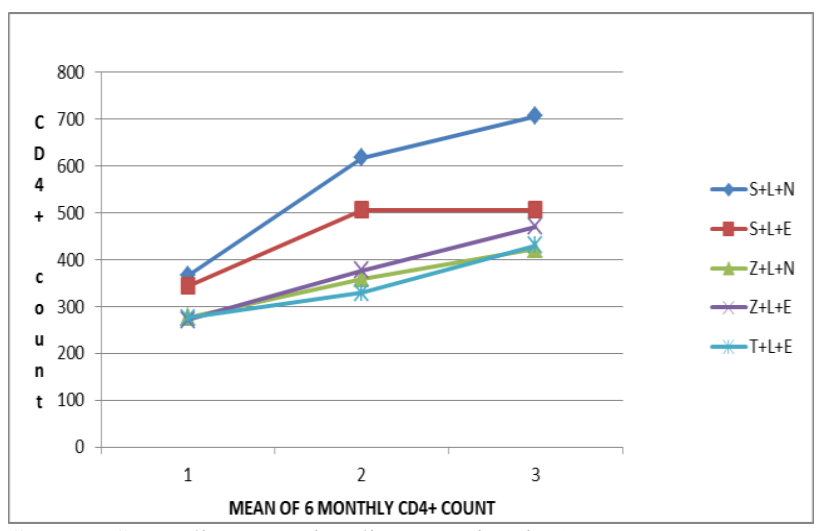

$\mathrm{S}+\mathrm{L}+\mathrm{N}($ Stavudine+Lamivudine+Nevirapine),

$\mathrm{S}+\mathrm{L}+\mathrm{E}$ (Stavudine+Lamivudine+Efavirenz),

$\mathrm{Z}+\mathrm{L}+\mathrm{N}$ (Zidovudine+Lamividine+Nevirapine,

$\mathrm{Z}+\mathrm{L}+\mathrm{E}$ (Zidovudine+Lamivudine+Efavirenz,

$\mathrm{T}+\mathrm{L}+\mathrm{E}$ (Tenofovir+Lamivudine+Efavirenz).

Figure 1: Line diagram showing various combination of anti-retroviral combination and there effect in rise inCD4+ cell count.

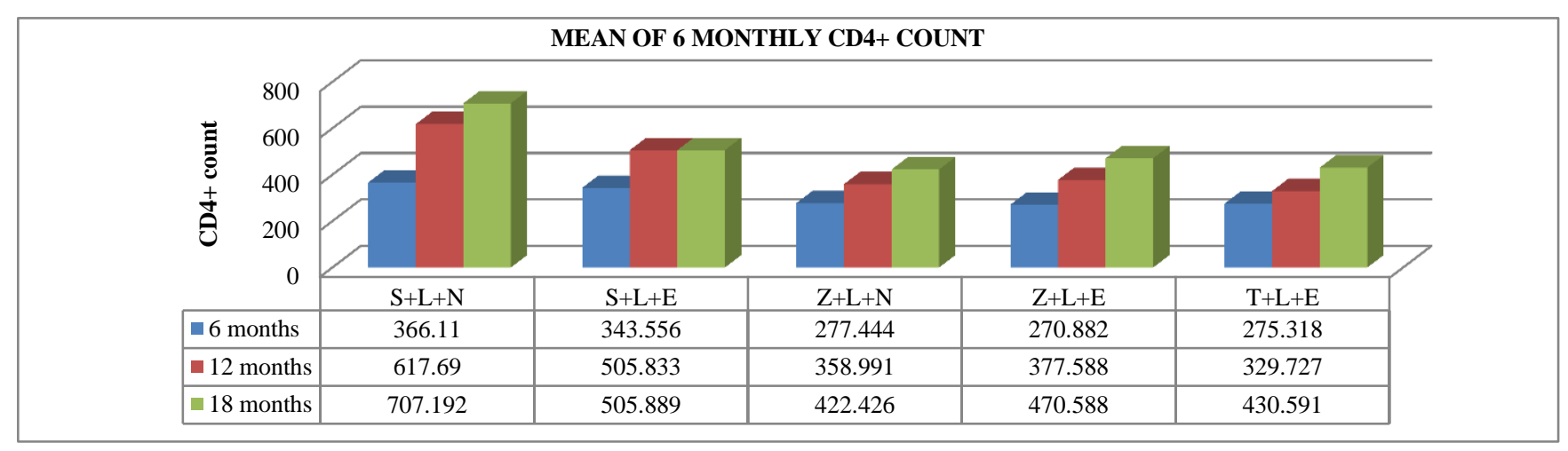

Figure 2: Change in CD4+ cell count change with HAART combination in every 6 monthly interval. 


\section{DISCUSSION}

CD4+ T-lymphocytes (CD4 cells) play a key role in HIV infection. HIV uses CD4 cells to replicate; and therefore resting CD4 cells can continue to harbour the virus with effective ART (anti-retroviral therapy). ${ }^{13,14}$ During the acute phase of infection the virus infects CD4 cells, viremia increases exponentially to very high levels and the concentration of $\mathrm{CD} 4$ cells in the plasma (CD4 count) drops by about $25 \%$. During the chronic phase of infection, which can last from about 2 to 20 years, the virus replicates in the peripheral lymphatic tissue and CD4 counts decline slowly. ${ }^{15-19}$ eventually to zero, but with increasing mortality and incidence of opportunistic infections, including tuberculosis. ${ }^{20,21}$ Recent studies suggest that combination therapy for HIV is most effective during acute phase of infection. ${ }^{22,23}$ A study from swiss COHORT stated that interruption from antiretroviral therapy was associated with decrease in CD4+ count, suggesting that adherence to ART not the viremia is most important in predicting the change in CD4+ cell count. ${ }^{24}$ Researchers have reported that the gradual CD4 cell count rise are likely to reflect the generation of new cells by peripheral expansion of preexisting T-cell clones or generation of typically derived naive cells among ART patients. ${ }^{25}$ Our present study showed that there is a sustained rise in CD4+ count in each treatment group which is followed up for 18 months which is consistent with other studies done. Gracia et al. found in a cohort study from Barcelona that, CD4 cells increased in the whole cohort $(<500$ cells $/ l)$ from a median of 214 cells $/ \mu 1$ to 499 cells $/ \mu 1$ ( $p<0.001)$. According to Patel et al. in $2 \mathrm{NN}$ study the nevirapine twice daily and efavirenz group showed median rise 160 cells $/ \mathrm{cm}^{26,27}$ by this study we can reveal that regime having S,L,N combination has better antiviremic activity in comparison to other group used in the treatment, the effectiveness of combination in decreasing order as follows SLN> SLE> ZLE>TLE>ZLN as shown in Figure 2 all these regimes are used for the treatment of HIV and the drug is decided according to patient's disease condition and adverse drug reaction and tolerance of the drug, whatever may be the condition we found that SLN regime is superior than any other regime used in this study.

\section{CONCLUSION}

Antiretroviral therapy is quite effective in suppressing viral replication delaying the progression of disease and has changed the management of HIV disease dramatically, yet issues of adherence, toxicity, emerging resistance and cost of second line drugs dominate the scenario.

The adherence to ART is one of the most crucial determinants of success of ART on long term basis, Long-term virologic suppression helps to ensure the recovery of CD4 cells to levels that reduce the risk of opportunistic infections and increase life expectancy.
Funding: No funding sources

Conflict of interest: None declared

Ethical approval: The study was approved by the Institutional Ethics Committee

\section{REFERENCES}

1. Phillips A, CASCADe Collaboration. Short-term risk of AIDS according to current CD4 cell count and viral load in antiretroviral drugnaive individuals and those treated in the monotherapy era. AIDS, 2004;18(1):51-8.

2. UNAIDS. The Gap report. 2014.

3. Medical bulletin/HIV AND AIDS IN INDIA-2016. Available at http://www.blogs.drdata.in/blog/hiv-andaids-in-india/.

4. Lewden C, Chene G, Morlat P. HIV-infected adults with a CD4 cell count greater than 500 cells $/ \mathrm{mm} 3$ on long-term combination antiretroviral therapy reach same mortality rates as the general population. J Acquir Immune Defic Syndr. 2007;46:72-7.

5. Gupta SB, Pujari SN, Joshi SR, Patel AK, For expert panel of Guidelines Development Committee - API Consensus Guidelines for use of Antiretroviral Therapy in Adults (API-ART Guidelines)- Journal Association of Physicians of India. 2006;54:57-74.

6. Panel on Antiretroviral Guidelines for Adults and Adolescents. Guidelines for the use of antiretroviral agents in HIV-1-infected adults and adolescents. Department of Health and Human Services, USA. 2008;1-128.

7. British HIV Association HIV Medicine. 2006;7:487503. Available at (http://www.bhiva.org/guidelines/2006/hiv/hivfs06.ht $\mathrm{ml})$.

8. Guidelines for Management of HIV-Infected Adults and Adolescents Including Post-exposure Prophylaxis, NACO. Ministry of health and Family Welfare; 2007.

9. Egger M, May M, Chene G. Prognosis of HIV-1 infected patients starting highly active antiretroviral therapy: a collaborative analysis of retrospective studies. 2002;360:119-29.

10. Stilianakis NI, Schenzle D. On the intra-host dynamics of HIV-1 infections. Math. Biosci. 2006;199:1-25.

11. Haase AT. Population biology of HIV-1 infection: viral and CD4+T cell demographics and dynamics in lymphatic tissues. Ann. Rev.Immunol. 1999;17:62556.

12. Katubulushi M, Zulu I, Yavwa F, Kelly P. Slow decline in CD4 cell count in a cohort of HIV-infected adults living in Lusaka, Zambia. AIDS. 2005;19:1023.

13. Detels R, English PA, Giorgi JV, Visscher BR, Fahey JL, Taylor JM, et al. Patterns of CD4+ cell changes after HIV-1 infection indicate the existence of a codeterminant of AIDS. JAIDS. 1988;1:390-5.

14. Lang W, Perkins H, Anderson RE, Royce R, Jewell $\mathrm{N}$, Winkelstein W. Patterns of T lymphocyte changes 
with human immunodeficiency virus infection: from sero conversion to the development of AIDS. JAIDS. 1989;2:63-9.

15. Lyles RH, Munoz A, Yamashita TE, Bazmi H, Detels $\mathrm{R}$, Rinaldo $\mathrm{CR}$, et al. Natural history of human immunodeficiency virus type 1 viremia after seroconversion and proximal to AIDS in a large cohort of homosexual men. Multicenter AIDS Cohort Study. J. Infect. Dis. 2000;181:872-80.

16. Williams BG, Dye C. Antiretroviral drugs for tuberculosis control in the era of HIV/AIDS. Science. 2003;301:1535-7.

17. Williams BG, Hargrove JW, Humphrey JH. The benefits of early treatment for HIV. AIDS. 2010;24:1790-1.

18. Freedberg KA, Losina E, Weinstein MC, Paltiel AD, Cohen CJ, Seage GR, et al. The cost effectiveness of combination antiretroviral therapy for HIV disease. N. Engl. J. Med. 2001;344:824-31.

19. Hammer SM, Squires KE, Hughes MD. A controlled trialof two nucleoside analogues plus Indinavir in persons with human immunodeficiency virus infection and CD4 cell counts of 200 per cubic millimeter or less. N Engl J Med. 1997;337:725-33.

20. Hogg RS, Yip B, Chan KJ. Rates of disease progression by baseline CD4 cell count and viral load after initiating Triple-Drug therapy. JAMA. 2001;286:2568-77.
21. Mocroft A, Phillips AN, Gatell J, Ledergerber B, Fisher M. Normalisation of CD4 counts in patients with HIV-1 infection and maximum virological suppression who are taking combination antiretroviral therapy: an observational COHORT study. 2007;370:407-13.

22. Gulick RM, Mellors JW, Havlir D, Eron JJ, Gonzalez C, McMahon D, et al. Treatment with indinavir, zidovudine and lamivudine in adults with human immunodeficiency virus infection and prior antiretroviral therapy. New England Journal of Medicine. 1997;337:734-9.

23. Gracia F, de Lazzari E, Plana M, Castro P, Mestre G, Nomdedeu M, et al. Long- term CD4+ T-cell response to highly active antiretroviral therapy according to baseline CD4+ T-cell count. Journal Acquired Immune Deficiency Syndrome. 2004;36:702-13.

24. Patel AK, Pujari S, Patel K, Patel J, Shah N, Patel B, et al. Nevirapine versus Efavirenz based antiretroviral treatment in naïve Indian patients: comparison of effectiveness in clinical cohort. Journal of the Association of Physicians of India. 2006;54:915-8.

Cite this article as: Mahato SK, Keshri USP, Kumar A, Protim P, Kumar V. To study the effect of various combinations of haart in CD4+ cell count in hiv patient at rims, ranchi art centre. Int J Basic Clin Pharmacol 2017;6:887-90. 